\title{
Struktur Sel Epidermis dan Stomata Daun Beberapa Tumbuhan Suku Orchidaceae
}

\author{
Yulanda Rompas ${ }^{1)}$, Henny L Rampe ${ }^{2)^{*}}$, Marhaenus $J$ Rumondor ${ }^{2)}$ \\ ${ }^{1)}$ Alumni Jurusan Biologi Fakultas MIPA Universitas Sam Ratulangi Manado \\ 2) Jurusan Biologi Fakultas MIPA Universitas Sam Ratulangi Manado \\ E-mail korespondensi :hennyrampe@yahoo.co.id
}

Diterima 2 April 2011, diterima untuk dipublikasikan 26 Juli 2011

\begin{abstract}
Abstrak
Telah dilakukan penelitian untuk menentukan struktur sel epidermis dan stomata pada beberapa tumbuhan anggota suku Orchidaceae yang merupakan anggota marga Arachnis, Phalaenopsis dan Vanilla. Metode deskriptif digunakan untuk menggambarkan struktur sel epidermis dan stomata daun anggrek kalajengking, anggrek bulan dan vanili berdasarkan pengamatan irisan memanjang sel-sel epidermis pada permukaan bawah daun dengan mikroskop cahaya. Hasil penelitian menunjukkan adanya variasi struktur sel epidermis dan stomata anomositik seperti pada tumbuhan dikotil.

Kata kunci: anggrek bulan, anggrek kalajengking, sel epidermis, stomata, vanili
\end{abstract}

\section{Abstract}

A research was conducted to determine the structure of epidermis and stomata cells on several Orchidaceae plants, such as genus Arachnis, Phalaenopsis and Vanilla. The descriptive method was used to describe the structure of epidermis and leaf stomata cells of scorpion orchids, moon orchids and vanilla by observing the epidermis of longitudinal section of lower leaf using light microscope. The research result showed that these plants had various structure of epidermis cells and had anomocytic type of stomata cells that was similar to dicotyledon plants.

Keywords: epidermis cell, moon orchids, scorpion orchids, stomata, vanilla

\section{PENDAHULUAN}

Tumbuhan tersusun dari berbagai organ seperti akar, batang, daun dan organ reproduksi. Organ-organ tersebut juga tersusun dari berbagai jaringan, seperti jaringan meristem, parenkim, sklerenkim, kolenkim, epidermis dan jaringan pengangkut (Woelaningsih 2001; Hidayat 1990).

Epidermis merupakan lapisan selsel paling luar dan menutupi permukaan daun, bunga, buah, biji, batang dan akar (Woelaningsih 2001). Berdasarkan ontogeninya, epidermis berasal dari jaringan meristematik yaitu protoderm (Sumardi dan Pudjoarinto 1994). Epidermis berfungsi sebagai pelindung bagian dalam organ tumbuhan. Berdasarkan fungsinya, epidermis dapat berkembang dan mengalami modifikasi seperti stomata dan trikomata (Kartasapoetra 1988).
Stomata biasanya ditemukan pada bagian tumbuhan yang berhubungan dengan udara terutama di daun, batang dan rizoma (Fahn 1991). Stomata umumnya terdapat pada permukaan bawah daun, tetapi ada beberapa spesies tumbuhan dengan stomata pada permukaan atas dan bawah daun. Ada pula tumbuhan yang hanya mempunyai stomata pada permukaan atas daun, misalnya pada bunga lili air. Bentuk atau tipe stomata dibedakan atas 4 yaitu anomositik, anisositik, parasitik dan diasitik (Lakitan 1993).

Menurut fungsi, bentuk, ukuran dan susunan sel-sel epidermis tidaklah sama atau berbeda pada berbagai jenis tumbuhan, demikian juga dengan bentuk atau tipe stomata (Fahn 1991). Walaupun berbeda epidermisnya, semua epidermis tersusun rapat satu sama lain dan membentuk bangunan padat tanpa ruang antar sel (Woelaningsih 2001). Jika 
terdapat ruang antar sel, misalnya epidermis mahkota bunga, ruang itu ditutupi oleh kutikula.

Suku Orchidaceae merupakan tumbuhan herba perenial yang dapat hidup terestrial atau epifit dan kadangkadang memanjat. Kelompok tumbuhan ini memiliki beberapa marga di antaranya adalah Arachnis, Phalaenopsis dan Vanilla (Dasuki 1991).

Setiap jenis tumbuhan mempunyai struktur sel epidermis yang berbeda. Perbedaan struktur sel epidermis yang dimaksud dapat berupa bentuk dan susunan sel epidermis, letak atau kedudukan stomata terhadap sel tetangga, arah membukanya stomata, bentuk stomata, jumlah sel epidermis dan stomata, jarak antara stomata dan panjang sel epidermis dan stomata.

Pengelompokan tumbuhan ke dalam tingkat marga pada suatu suku, umumnya berdasarkan bentuk morfologi organ tumbuhan seperti bentuk daun dan bunga. Tumbuh-tumbuhan yang memiliki banyak persamaan dikelompokkan ke dalam satu marga yang sama. Tumbuhan suku Orchidaceae seperti anggrek kalajengking (Arachnis flos-aeris), anggrek bulan (Phalaenopsis amabilis) dan vanili (Vanilla planifolia) dikelompokkan ke dalam marga yang berbeda karena mempunyai struktur morfologi daun dan bunga yang berbeda. Anggrek kalajengking memiliki daun tebal berdaging dan bunga terdapat pada setiap tangkai dan berbentuk seperti kalajengking. Anggrek bulan memiliki daun tebal, kaku, panjang dan bunga tersusun rapat, berjajar, dua baris sebelah menyebelah tangkainya, sedangkan vanili memiliki daun pipih, berdaging, bulat telur, jorong atau lanset dengan ujung lancip dan bunga merupakan bunga tandan yang terdiri dari 15-20 bunga.

Ada tidaknya kaitan antara perbedaan struktur morfologi daun dan bunga dengan perbedaan struktur sel epidermis dan stomatanya masih belum diketahui. Kajian struktur epidermis dan stomata tumbuhan dari suku Orchidaceae juga masih terbatas. Oleh sebab itu penelitian ini perlu dilakukan untuk memberikan informasi ilmiah tentang struktur sel epidermis dan stomata tumbuhan suku Orchidaceae khususnya anggrek kalajengking, anggrek bulan dan vanili.

Penelitian ini bertujuan untuk menggambarkan struktur sel epidermis dan stomata pada daun tumbuhan suku Orchidaceae khususnya anggrek kalajengking, anggrek bulan dan vanili.

\section{METODOLOGI PENELITIAN Alat dan Bahan}

Peralatan yang dipakai adalah mikroskop cahaya, optilab, laptop, kaca benda, kaca penutup, pipet tetes, silet, kertas label, labu Erlenmeyer dan kamera digital. Bahan digunakan adalah masingmasing 5 helaian daun anggrek kalajengking (Arachnis flos-aeris), anggrek bulan (Phalaenopsis amabilis), vanili (Vanilla planifolia), safranin dan air.

\section{Metode Penelitian}

Penelitian ini menggunakan metode deskriptif untuk menggambarkan dan menginterpretasi struktur sel epidermis dan stomata daun beberapa tumbuhan suku Orchidaceae

\section{Prosedur Penelitian}

Pada penelitian ini dibuat preparat segar irisan memanjang permukaan bawah epidermis daun anggrek kalajengking, anggrek bulan, vanili, untuk mengamati struktur sel epidermis dan stomatanya. Langkah-langkah yang dilakukan (Woelaningsih 1984; Hidayat dan Suradinata, 1990) adalah sebagai berikut:

1. Pengambilan sampel dilakukan pada pagi hari. Anggrek kalajengking diambil dari Kota Tomohon, lalu dimasukkan dalam cool box yang berisi es dan dibawa ke lokasi penelitian. Anggrek bulan dan vanili diambil di Kota Manado, dan tidak dimasukkan dalam cool box karena dekat dengan lokasi penelitian.

2. Daun yang telah berkembang sempurna dipakai sebagai sampel untuk dibuat irisan memanjang permukaan bawah daun.

3. Masing-masing irisan diletakkan pada kaca benda, lalu ditetesi dengan air. 
Setetes larutan safranin 0,05\% ditambahkan untuk memperjelas pengamatan. Preparat ditutup dengan kaca penutup dan diamati di mikroskop pada pembesaran 10X10.

4. Mikroskop dihubungkan dengan optilab jika sudah mendapatkan gambar yang diinginkan dan pembesaran berubah menjadi 268X (Anonim 2010). Selanjutnya dilakukan pengambilan gambar (image capture) dengan optilab dan hasilnya dapat dilihat langsung di monitor laptop.

\section{Pengamatan}

Struktur sel epidermis dan stomata diamati untuk satu bidang pandang dengan perbesaran 268X. Struktur sel epidermis dan stomata daun beberapa tumbuhan suku Orchidaceae meliputi:

1. Bentuk (bersegi, memanjang atau tidak beraturan) dan susunan sel epidermis (sejajar satu sama lain, saling tegak lurus).

2. Letak atau kedudukan stomata terhadap sel tetangga dengan mengamati jumlah sel tetangga yang mengelilingi stomata.

3. Arah membuka stomata (sejajar atau tegak lurus terhadap sel tetangga sebelah kiri dan kanan).

4. Bentuk stomata (berbentuk ginjal atau halter)

5. Jumlah sel epidermis dan stomata

Untuk menghitung jumlah sel epidermis (termasuk sel tetangga) dan stomata, hanya dilihat sel yang utuh, sedangkan sel yang tidak utuh tidak dihitung (diabaikan)

6. Jarak antar stomata satu dengan yang lain ke segala arah

7. Panjang sel epidermis dan stomata Pengukuran sel epidermis dan stomata yang utuh adalah pada sisi yang terpanjang menggunakan aplikasi Optilab Image Raster dengan satuan $\mu \mathrm{m}$.

\section{Analisis data}

Data yang diperoleh dianalisis secara deskriptif, yaitu menggambarkan dan menginterpretasi struktur sel epidermis dan stomata daun.

\section{HASIL DAN PEMBAHASAN \\ Struktur Sel Epidermis dan Stomata Daun Anggrek Kalajengking}

Bentuk sel epidermis anggrek kalajengking (Arachnis flos-aeris) ada yang memanjang, segi lima, segi enam, dan tidak beraturan. Walaupun terdapat perbedaan bentuk sel epidermis, tetapi secara ontogeni epidermis merupakan jaringan yang seragam. Susunan sel epidermis tersusun rapi dan searah, mempunyai struktur morfologi dan anatomi yang kokoh karena tersusun dari sel yang rapat satu sama lain atau tidak terdapat ruang antar sel (RAS) dan pada pengamatan ini nukleus tidak teramati (Gambar 1).

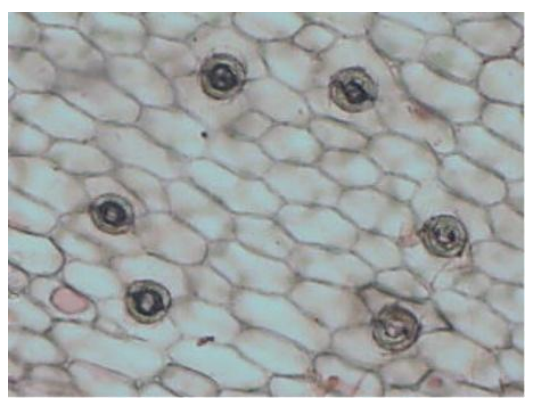

Gambar 1. Struktur sel epidermis dan stomata daun anggrek kalajengking (Arachnis flos-aeris)

Stomata daun anggrek kalajengking dikelilingi oleh 4 sel tetangga, 2 sel tetangga sejajar pada setiap sisi yaitu pada bagian kanan dan kiri, dan 2 sel tetangga lainnya terletak pada masingmasing ujung poros. Jumlah dan susunan sel tetangga ditentukan oleh suku tumbuhan tersebut (Salisbury dan Ross 1995). Pada daun yang bertulang sejajar, stomata tersusun dalam deretan memanjang dan pembentukan stomata dimulai dari ujung sampai ke arah dasar daun atau basipetal (Hidayat 1995). Arah membuka sel penutup stomata sejajar terhadap sel tetangga.

Stomata anggrek kalajengking berbentuk ginjal dan tergolong tipe anomositik seperti pada tumbuhan dikotil. Stomata ini teramati dalam posisi terbuka, dan terlihat porus atau celah yang terbuka (Gambar 3). Stomata membuka karena sel penutup mengambil air dan mengembung (Salisbury dan Ross 1995). 
Bertambah dan berkurangnya ukuran celah pada sel penutup adalah akibat perubahan tekanan turgor pada sel penutup (Fahn 1991). Porus atau celah di antara sel penutup terbentuk karena retakan pada membran selnya (Kartasapoetra 1988).

\section{Struktur Sel Epidermis dan Stomata Daun Anggrek Bulan}

Sel epidermis pada tumbuhan anggrek bulan hampir sama dengan anggrek kalajengking yaitu berbentuk segi lima, segi enam, bahkan ada yang bentuknya tak beraturan dan hanya terdiri dari selapis sel. Susunan sel epidermis ini tidak beraturan satu sama lain. Letak selsel epidermis ini sangat rapat sehingga tidak terdapat ruang-ruang antar sel (non intercellular spaces). Pada masing-masing sel terdapat inti yang umumnya terletak di tengah (Gambar 2).

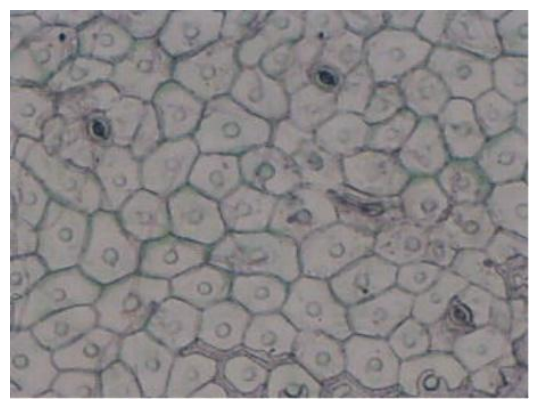

Gambar 2. Bentuk sel epidermis dan stomata daun anggrek bulan (Phalaenopsis amabilis)

Stomata dikelilingi oleh 4-5 sel tetangga dan dua sel tetangga masingmasing terdapat di samping sebuah sel penutup (Gambar 2) yang merupakan ciri tumbuhan monokotil (Hidayat 1995). Arah membuka sel penutup stomata sejajar terhadap sel tetangga. Stomata berbentuk ginjal dan memiliki tipe anomositik serta teramati dalam posisi terbuka dan tertutup.

\section{Struktur Sel Epidermis dan Stomata Daun Vanili}

Bentuk, serta susunan sel-sel epidermis sangat bervariasi. Sel epidermis berbentuk segi lima, segi enam, memanjang, dan bahkan ada yang tidak beraturan. Kedudukan sel epidermis tidak beraturan satu dengan yang lain dan terdapat ruang antar sel. Pada sel epidermis ini ditemukan inti yang terletak di tengah dan ada yang terletak di tepi sel (Gambar 3). Sel epidermis merupakan sel hidup, mempunyai protoplas, sitoplasma biasanya hanya berupa selaput tipis yang melekat pada dinding sel (Sumardi dan Pudjoarinto 1994), tetapi protoplasnya tidak dapat teramati pada preparat ini. Sel epidermis ini juga mempunyai kloroplas pada sel penutupnya.

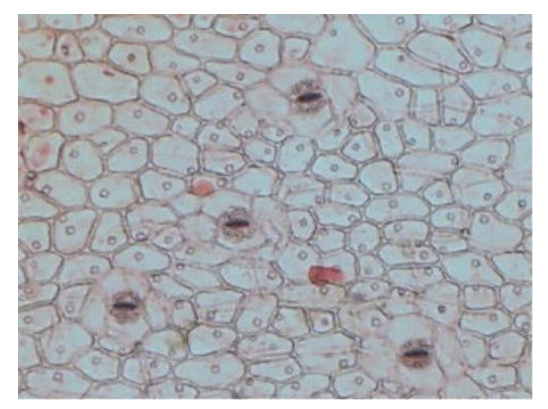

Gambar 3. Struktur sel epidermis dan stomata daun vanili (Vanilla planifolia)

Stomata dikelilingi oleh 4 sel tetangga, tersusun teratur membentuk lingkaran mengelilingi stomata (Gambar 3). Sel tetangga biasanya berkembang dari sel protoderm yang berbatasan dengan sel induk stomata (Fahn 1991). Arah membuka stomata sejajar terhadap sel tetangga. Letak stomata berderet atau tersebar sulit ditentukan pada pengamatan stomata ketiga macam tumbuhan tersebut, karena luas pandang pengamatan terlalu kuat dengan pembesaran 268X.

Berbeda dengan posisi stomata pada anggrek kalajengking dan anggrek bulan dalam posisi terbuka, bentuk stomata vanili dalam posisi tertutup dan berbentuk ginjal. Hal ini memberikan informasi bahwa tidak semua tumbuhan monokotil memiliki stomata bentuk halter. Tumbuhan suku Orchidaceae khususnya tumbuhan anggrek kalajengking, anggrek 
bulan dan vanili memiliki stomata bentuk ginjal dan memilki tipe anomositik (kecuali vanilli).

\section{Jumlah Sel Epidermis dan Stomata, Serta Jarak Antar Stomata}

Rata-rata jumlah sel epidermis vanili lebih tinggi dibandingkan dengan anggrek bulan dan anggrek kalajengking. Sedangkan rata-rata jumlah stomata anggrek kalajengking lebih tinggi dibandingkan dengan anggrek bulan dan vanili (Tabel 1).

Tabel 1. Rata-rata jumlah sel epidermis (termasuk sel tetangga) dan stomata daun anggrek kalajengking, anggrek bulan dan vanili (perbesaran 268X) dengan luas bidang pandang yaitu 640X480 $\mu \mathrm{m}$

\begin{tabular}{|c|c|c|c|}
\hline No & $\begin{array}{c}\text { Nama } \\
\text { Tumbuhan }\end{array}$ & $\begin{array}{c}\text { Rata-rata } \\
\text { jumlah sel } \\
\text { epidermis }\end{array}$ & $\begin{array}{c}\text { Rata- } \\
\text { rata } \\
\text { jumlah } \\
\text { stomata }\end{array}$ \\
\hline 1 & $\begin{array}{c}\text { Anggrek } \\
\text { kalajengking }\end{array}$ & 65 & 6 \\
\hline 2 & $\begin{array}{c}\text { Anggrek } \\
\text { bulan }\end{array}$ & 101 & 3 \\
\hline 3 & Vanili & 126 & 4 \\
\hline
\end{tabular}

Rata-rata jarak antar stomata anggrek bulan lebih panjang dibandingkan dengan vanili dan anggrek kalajengking (Tabel 2). Jika jumlah stomata sedikit dalam satu bidang pandang, maka jarak antara stomata akan semakin panjang sedangkan jika jumlah stomata banyak dalam satu bidang pandang, maka jarak antara stomata semakin pendek.

Jumlah stomata yang dapat diamati pada anggrek kalajengking bervariasi untuk luas bidang pandang yang sama yaitu 268X pembesaran. Jumlah stomata terbanyak ialah 6 , sedangkan yang paling sedikit adalah 5 dengan jarak antara stomata yang tidak menentu. Jarak melebar stomata yang tersebar dengan jarak yang kurang lebih sama adalah khas bagi spesies tumbuhan tertentu (Sachs 1978 dalam Fahn 1991). Daerah bebas stomata di sekitar setiap stoma dapat disebabkan oleh 1) terhambatnya pertambahan stomata karena diferensiasi yang telah ada, 2) pembentukan stoma bersama-sama dengan sel-sel yang mengelilinginya sebagai bagian dari pola perkembangan yang sama, 3) induksi pola stomata oleh pola jaringan dasar, yaitu mesofil.

Tabel 2. Rata-rata jarak antara stomata

\begin{tabular}{|c|c|c|}
\hline No & Nama Tumbuhan & $\begin{array}{c}\text { Rata-rata jarak } \\
\text { antar stomata } \\
(\mu \mathrm{m})\end{array}$ \\
\hline 1 & $\begin{array}{c}\text { Anggrek } \\
\text { kalajengking }\end{array}$ & 83,77 \\
\hline 2 & Anggrek bulan & 104,32 \\
\hline 3 & Vanili & 96,46 \\
\hline
\end{tabular}

Jumlah stomata vanili yang paling banyak teramati berjumlah 5 stomata, sedangkan yang paling sedikit berjumlah 4 stomata. Jumlah stomata bervariasi pada daun tanaman yang sama dan juga pada daerah-daerah daun yang sama (Hidayat 1990).

Pada anggrek bulan, jumlah stomata yang teramati adalah 3 stomata pada pembesaran yang sama, dan merupakan jumlah paling sedikit dibandingkan dengan anggrek kalajengking dan vanili. Jumlah stomata berkurang dengan menurunnya intensitas cahaya. Hal ini sangat berhubungan dengan habitat dari tanaman anggrek bulan yang hidup di bawah naungan yang tidak mendapat sinar matahari langsung (Pazourek 1970) dalam Fahn 1991). Kerapatan stomata sangat bergantung pada konsentrasi $\mathrm{CO}_{2}$, yaitu bila $\mathrm{CO}_{2}$ naik jumlah stomata per satuan luas lebih sedikit (Woodward 1987 dalam Salisbury dan Ross 1995).

Panjang Sel Epidermis dan Stomata 


\begin{abstract}
Rata-rata panjang sel epidermis dan stomata anggrek kalajengking lebih panjang dibandingkan anggrek bulan dan vanili (Tabel 3).
\end{abstract}

Tabel 3. Rata-rata panjang sel epidermis dan stomata daun anggrek kalajengking, anggrek bulan, dan vanili (perbesaran 268X) dengan luas bidang pandang yaitu $640 \mathrm{X} 480 \mu \mathrm{m}$

\begin{tabular}{|c|c|c|c|}
\hline No & $\begin{array}{c}\text { Nama } \\
\text { Tumbuhan }\end{array}$ & $\begin{array}{c}\text { Rata-rata } \\
\text { panjang } \\
\text { sel } \\
\text { epidermis } \\
(\mu \mathrm{m})\end{array}$ & $\begin{array}{c}\text { Rata-rata } \\
\text { panjang } \\
\text { stomata } \\
(\mu \mathrm{m})\end{array}$ \\
\hline 1 & $\begin{array}{c}\text { Anggrek } \\
\text { kalajengking }\end{array}$ & 33,24 & 19,68 \\
\hline 2 & $\begin{array}{c}\text { Anggrek } \\
\text { bulan }\end{array}$ & 22,78 & 10,03 \\
\hline 3 & Vanili & 19,68 & 10,81 \\
\hline
\end{tabular}

Sel-sel epidermis daun anggrek kalajengking lebih besar dibandingkan dengan sel-sel epidermis pada daun anggrek bulan dan vanili. Bertambahnya ukuran sel atau keadaan sel membesar sangat berhubungan dengan pertumbuhan daun memanjang dan melebar. Untuk pelebaran helaian daun, sel di bawah pemula marginal (pemula submarginal) akan berperan. Pembelahan sel pemula terjadi berulang kali sehingga terjadi meristem papan yang mengakibatkan melebarnya helaian daun. Adanya meristem papan menyebabkan bertambahnya ukuran daun. Ukuran daun yang bertambah, diakibatkan oleh ukuran sel yang bertambah (Hidayat 1995). Sel epidermis diukur berdasarkan sisi yang terpanjang karena sulit untuk menentukan ukuran sel yang bentuknya agak rumit seperti segi lima dan segi enam, atau yang tidak beraturan. Pengukuran hanya dilakukan pada sel yang lengkap atau utuh, sedangkan untuk sel yang tidak utuh diabaikan.

\section{KESIMPULAN}

Bentuk sel epidermis anggrek kalajengking, anggrek bulan dan vanili bervariasi yaitu memanjang, segi lima, segi enam dan ada yang tidak beraturan. Susunan sel epidermis anggrek kalajengking searah, sedangkan susunan epidermis anggrek bulan dan vanili tidak beraturan. Stomata anggrek kalajengking dan vanili dikelilingi oleh 4 sel tetangga, sedangkan anggrek bulan dikelilingi oleh 4-5 sel tetangga. Stomata ketiga tumbuhan ini berbentuk ginjal dan memiliki tipe anomositik (kecuali vanili) seperti pada tumbuhan dikotil. Rata-rata jarak antara stomata anggrek kalajengking adalah 83,77 $\mu \mathrm{m}$, anggrek bulan 104,32 $\mu \mathrm{m}$ dan vanili $96,46 \mu \mathrm{m}$.

\section{DAFTAR PUSTAKA}

Anonim (2010) www.IndoGama.com.optila blIndoGama_com OPTILAB Microscope Camera (Kamera Mikroskop).htm. Diakses pada 1 Mei 2010

Campbell NA, Reece JB, Mitchell LG (1999) Biologi Jilid 2, Edisi ke-2. Erlangga, Jakarta

Dasuki UA (1991) Sistematik tumbuhan tinggi. Bidang Ilmu Hayati ITB, Bandung

Esau K (1977) Anatomy of seed plant. Wiley Eastern Private Ltd, New Delhi

Fahn A (1991) Anatomi tumbuhan, Edisi ke-3. Gadjah Mada University Press, Yogyakarta

Hidayat EB (1990) Dasar-dasar struktur dan perkembangan tumbuhan. ITB, Bandung 1995. Anatomi tumbuhan berbiji. ITB, Bandung

Hidayat EB, Suradinata TS (1990) Penuntun praktikum anatomi tumbuhan. F-MIPA ITB, Bandung

Kartasapoetra AG (1988) Pengantar anatomi tumbuh-tumbuhan (tentang sel dan jaringan). Bina Aksara, Jakarta

Lakitan B (1993) Dasar-dasar fisiologi tumbuhan. Raja Grafindo Persada, Jakarta

Salisbury FB, Ross CW (1995) Fisiologi tumbuhan Jilid 1. ITB, Bandung 
(1995)

Fisiologi tumbuhan Jilid 2. ITB, Bandung.

Sumardi I, Pudjoarinto A (1994) Struktur dan perkembangan tumbuhan. Fakultas Biologi UGM, Yogyakarta

Sutrian Y (2004) Pengantar anatomi tumbuh-tumbuhan. Rineka Cipta, Jakarta

Woelaningsih S (2001) Struktur dan perkembangan tumbuhan II. Fakultas Biologi UGM, Yogyakarta

(1984) Penuntun praktikum botani dasar. Laboratorium Anatomi Tumbuhan Fakultas Biologi UGM, Yogyakarta 